\title{
Reunification of Korea: Economic Consequences from an External Point of View"
}

\author{
EDWARD M. GRAYAM**
}

Korean reunification remains an uncertainty. When and if it comes, the condition of the North Korean economy is primitive compared to the economy of South Korea. Because of massive investment needs in the North, and under plausible assumptions regarding savings rates in a unified Korea, the balance of paymont of a reunified Korea is likely to detcriorate significantly in the event of reunification. Foreign direct investment could ameliorate this result, and might contribute to a more rapid catch-up of the North to the South.

Kegwords: Korean reunification, conomic effects of Koreno teunification, balance of payments effects of Korean reunification

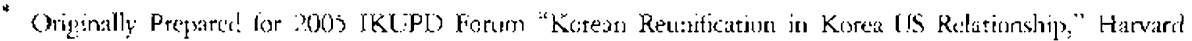
Law Schiol, April 9, 2005.

"The aurhor would like to thank Ted Kim, Jirs: Luster, Paui Karner, Mascus Nolane, tun persons

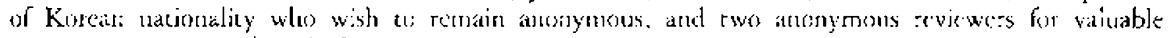
comments on an earlier deaft.

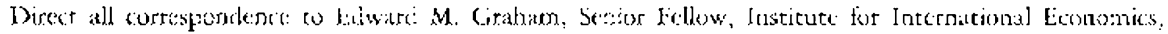

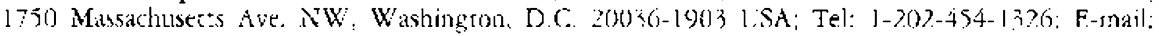
Moncy.Grahanki we.com 


\section{IN'TRODUCTION}

A

Imost all Kortans dream that the "two Koreas," the Republic of Korea (ROK) in the south and the Democratic People's Republic of Korea (DPRK) in the nurth, rcunify. This drcam, of course, has not been realized. During the early to mid-1990s, there was some expectation that the DPRK's economy mighe collapse, bringing about reunification similar to Germany's some ycars carlicr (see Noland 2004 for a review of studies predicting South Korean collapse. See also Ebcrstadt 2004). But this has not happened, and few analysts now expect such a collapse in the near futurc. Morcover, DPRK's withdrawal from the Nuclear Nonproliferation 'l'reaty (NP'l) and statements by the DPRK leadership announcing that the DPRK is a nuclear power have greatly complicated matters. This announcement also violated an early 1990s accord with South Kotea. the Accord on Development of the Peninsula, and the 1991 Agreed Framework with the United States. Relations between the United Stutcs and the DPRK, neither ever warm nor friendly, have become significintly cosler since this announcement.

This is certainly so relative to the period of the Agreed Framework negoriated under the Bill Clinton administration. Relations have become cooler with the Bush administration, with President Genrge W. Bush proclaiming the DPRK to be part of the "Axis of Fvil" as well as an "Outpost of Tyranny." The Clicago Council on Forciga Rclations publishes "temperatures" of relations among countries, based on polls of opinion leaders. "The "temperature" of the LS-North Korean relationship was a frosty thirty-four[a1] in 2002, but chilled further to twenty-eight in 2004[a2]. This latter reading tied for the lowest "temperature" of US relations with any country during the past fifeen years (the temperature of the US-Iraq relationship was also ewenty-cight prior to the l'S invision of that conntry). For sake: of comparison, one might note that the "warmest" United States relationships are with Canada and the Linited Kingdom, at seventy-scver and seventy-six, respectively[a3\}.

During the administration of Kim Dae-jung (1998-2003). the ROK pursued the sunstine policy, whereby greater contact and better relations with the DPRK were sought (the ROK and the DPRK were, and currently are, technically in a state of war when Kim Dae-jling took office). As part of this policy, South Kurear: firms, principally onces belonging to the Hyundai group, undertook investmonts in the DPRK, mostly in Kaesong Industrial Park located near Pyongyang or in the resort complex devcloped by llyurkdai in the Mount Kumgang (Kurngangsan) region. By almost all accounts, these undertakings have been money-losers for Ilyundai. Indeed, the 2004 bankruptey of the once-flagship firm of the Hyundai group, Hyundai Fngineering and (onstrucrion Company (HICC), would seen dosely related to the large cash flow drain creared by these undertakings: especially at Mr. Kunlrang. ${ }^{1}$ The sunshine policy also resulted in a linnited number of reunifications of familiss separated by the partition of Korea following the Korean War of the early 1950s, and largely unfulfilled plars to re-lirk the two Koreas by rail. Although 
the current ROK administration under Roh Moo-hyun has pledged to continue the sunshine policy de facto, this policy secms to have been ignificantly scaled back.

Thus, Korean reunification remains mostly a drcam. A limited number of exchanges continue, especially in the ficld of sports. Sports cxchanges have brought to the ROK such phenomena as the weeping North Korean cheerleaders, arguably the best propaganda instrument in the South that the North has yet devised (they arc young, innocent-looking, and attractive). Sympathy for the North in fact docs scem to be stong in the South, especially among young persons who also tend to despise the policies of the US' Bush administration, such that the North is able to play off of this sentimert by appealing to Korean nationalism. But even so, Korean unification seems distant even to youlluful South Koreans who, sentiment asicle, are also aware that the DPRK remains a cletatoship where there are widely reported human rights abuses carried out under the leadership of a man who trics to secm charismatio but of en comes across as simply eccentric. Fven youthful South Koreans are aware thar a large number of the DPRK's own residents would like to emigrate but arc forcitly prevented from doing so.

Even so, surprises happen (who in 1988 would have guessed that, three vears later, West and East Germany were to be reunited?). Were the ROK and the DPRK to be reunited, it is worthwhile to ask what the effects would be on the ROK itself and on other nations that might be affected. In the remainder of this paper, I will attempt to look at what these effects might be from an economics poirt of view. As I do tot claim to have the expertise to go beyond economics, this examination will laredy be limited to economic and not social and political consecpliences (very important issies that are out of my area of competence).

To this end, it is worth looking at some major contrasts berwecn the ROK and the DPRK. If the two Korcas were to reunite, the result would be:?

1) A country whose land mass had increased by a factor of 2.2 times.

2) A country whose population increased by about $46 \%$ (the combined population would be about $146 \%$ that of the present ROK). There is somewhat more ethnic diversity in the North than in the South, mostly duc to the relatively larger presence of ethnic Chincse in the North. Thus, reunification would reduce somewhat the ethric homogeneity of the nation, or at least from the perspective of the South.

3) A country where the median age of the population would drop slighty; the ROK, similar to most high income (and some middle income) nations, face thi future problem of the graying of the population, such that elderly poople who are no longer cconomically productive will grow as a percentage of the population. Reunification with the DPRK would delay this problem somewhat, but it would eventually still come to pass.

1) A country whose per capita income would be, in the early years following 
reunification, significantly lower than that of the ROK's current level.

On this last point, the per capita income of the ROK in 2003 was, at purchasing power parity rates, about LS\$17,800 while the per capita income of the DPRK was only US $\$ 1,300.3^{3}$ On this basis, if reunification with the North had been achieved in 2003, purchasing power parity per capita GDP of the unified nation would have been about $\$ S 12,500$. Also, of course, there would also be created major income incqualicy between residents of the northern portion of the reunified country and those of the southern portion at the outset.

\section{ECONOMIC EFFECTS OF REUNIFICATION ON 'IHE ROK}

By a number of measures, reunification would place large economic sosts on the South. Or, at least, this would be so if following reunificarion, the effort were to be made to raise North Korean incomes to levels approaching those of the South. Much of these costs would involve heavy investmenr in necessary infrastructure upgrades. For example, North Korea has only about $2,000 \mathrm{~km}$ of paved highways while almost $30,000 \mathrm{~km}$ of roads in the North are unpaved.t In the South, by contrast, $65,000 \mathrm{~km}$ of paved roads exist on a smaller land mass. Moreover, the quality of the paved roads in the South is much higher than in the North. In the South, there are over $2,300 \mathrm{~km}$ of oil and gas pipeline; the North, only 154 $\mathrm{km}$ of these pipelines. There are eighty-eight airports in the South with paved runways, of which three are large international airports. In the North, there are thirry-five airports with paved runways. Threc of these have runways capable of handling long distance international flights, but have inadcquate terminal facilities to handle a large volume of passenger or freight traffic. Most transport, both of goods and passengers, in the North is reportedly by railway. There are 5,214 $\mathrm{km}$ of railsiays of standard gauge, but visitor reports indicate that much of the railroad is in poor repair. In the South, there are fewer railway lines $(3,125 \mathrm{~km}$ of railways of standard gauge), but these include vory nodern high-speed rain lines that are lacking in the North.

Other differences in infrastructure can be cited. 'lhete are, for cxample, I.1 million telephones in the North, or barely one telephone for every twenty residents, all of which are, at least officially, land-lines. Near the Chinese border, however, North Koreans have been able to buy cell phones that utilize Chinese transmission facilitics. These are illegal, but the number of such phones is believed to be about 20,000 . In the South, there are 22.8 million landlines and, as of $2003,33.6$ million mobile telephones, or more than onc telephone per resident. The quality of telephone service in the North has nut been assessed by experts, but visitors report that it is quite poor. By contrist, the quality of telephone service in the South is considered excellent by international standards. 
In the North, total electricity consumption in 2001 was 27.91 billion kilowatt-hours, or abour $1,200 \mathrm{KWH}$ per capita. In the South, total electricity consumprion was 270.3 billion $\mathrm{KWH}$, or about $5,560 \mathrm{KWH}$ per capita (close to times times the per capita consumption in the North). Moreover, powet plants in the North are generally quite old and in need of modernization or replacement. One report indicates that only sixty-two generating facilities in the North (out of about 500) were actually functioning in 2000 (von Hippel, Savage, and Hayes 2005). Unlike the South, the North faces a shortage of potable water, and modern sewage is gencrally lacking in the North. With the latter, however, there is also a necd to upgrade sewage facilitics in the Sourth.

Indeed, there is a belief among cconomists that the overall capital stock of North Korca has deteriorated substantially during the decade and a half since the fall of the Sovier Linion (which provided investment in the DPRK), so much so that the North might be in a poverty trap (new capital goods are not being added quickly enough even to replace worn-out capital). Babson and Yoon (2004) report that at least US $\$ 5$ billion would be required to creatc enough additional capital to bring the North out of this trap.

It must be noted that in spite of the above, there are factors in the Nurth that are economically favorable rclative to the South. Not only is the amount of land in the North greater than in the South, and less-densely populated, but the percentage of arable land in the Norch is greater than in the South $(20.8 \%$ in the North as opposed $1017.2 \%$ in the South). However, soil erosion and degradation put some constraints on the North Korcan agricultural sector and, in the event of reunification, the unified nation will doubtlessly face a large bill for soil restoration in the North. North Korea contains more natural resources than South Kurca. In the DPRK, mining is a major economic activity whereas mining hardly figures in the $\mathrm{KOK}$ 's economy.

Education at least at the elementary level seems to be a prerequisite for a poor country to conter into a period of rapid economic development and growith. On this score, the DPRK would seem to be in good condition; adult literacy in the DPRK approaches $99 \%$, among the highest in the workd. Also, an important indicator of social welfare is life expectancy at birth; this is 71.1 years in the DPRK, 75.0 years in the ROK. These life expectancy figures, from the CIA, do not apparently include effects of the famine in North Korea during the late 1990 s. Estimates of deaths duc to this famine range from under a quarter of a million to more than 3 million.

But on the whole, this would suggest that healthcare in the North is actually quite good, or at least so for a rather poor country (and in spite of some reports to the contrary). However, some of the difference in life expectancy can in fact be attributed to a much higher infant mortality rate in the North. There are 7.1 deaths per 1,000 live birchs in the South versus more than twenty-four deaths per 1,000 live births in the North. Even so, overall. life expectancy is high and 
infant mortality low in the North compared to other countries at comparable per capia income. Also, while women outive men on average in both Koreas, the average number of years lived by men relative to women is lower in the South (0.90) than in the North (0.92). Thus, longer overall life expectancy in the South relative to the North would seem to be due in some measure to robust South Korean vomen.

While natural resources favor the North and human capital/human health do not seem to disfawor the North unduly relative to the South, apart fron the military sector, the industrial structure of North Kores is relatively primitive and technology non-intensive compared to that of South Korea. $\Lambda$ s such, major industries in the DPRK include the basic metallurerical industries, machine building, textiles, and food proxessing. Major industries in the South are much more technologically intensive and include electronics, telecommunications, automobiles, chemicals, shipbuilding, and what is presently the world's most efficient stecl-making sector. Per capita income differences berween the North and the South, moreover, are caused by differences in overall productivity, this productivity clearly much higher in the South. Some of the difference is due to different sectoral distributions of the working population. In particular, a much higher percentage of North Korea's working population is in the relatively low-productivity agricultural sector, though the exact percertage is unclear. But the following figures are indicative: in the South, less than $4 \%$ of $G D P$ comes from this sector. whereas in the North, more than $30 \%$ of GDP comes trom the agricultural sector. Almost surely, then, at leass $30 \%$ of the working population in the Norh works in agriculture, a far highes percentage than in high-income countries including the ROK, and likely an understated percentage. On this, it mighe be noted that in recent years, upwards of $60 \%$ of China's workforce is employed in the agricultural sector, altheit this percent is dropping each year.

A huge difference between the economies of the ROK and DPRK is the intensity of exports. Toxal exports of the South in 2003 were valued at about US\$201 billion, or about LSS'1, L 10 per capica. 'Iotal reported exports of the North were orly about US\$1.01 billion in 2002, or about US\$16 per capita. Incredibly, then, exports per capita of the South were almose 100 cirmes greater than those of the Vorth. Flowever, the North probably exports about US\$500 millon in weapons that are not reported in the above figures, and an unknowable quanrity of illicit drugs. Even so, if the value of illicit drug exports plus unreported weapons exports total as much as US\$ 1 billion, the exports per capita of the South are still at least fifty times greater than those of the North.

Indecd, South Korea is the tenth largest econony in the world today. If the South is reunified with the North, the combined country will still be in tenth place. The combined country would mortover no longer be classed arnong the workd's high-incone countrics by the Workd Bank, but would fall into the middle-income category. To be sure, if and when per capita incomes in the North rose 
to equal those of ehe South, the combined country would regain its former position as a high-income country. But, if economic growth rates in the North could be sustained at rates comparalsle to those in the Sorth butwecn the late $1960 \mathrm{~s}$ and the late 1900 (), this per capita income equalization would take at least thirry ycars to achieves. Many analysts think, however, that this "transition period" could he a lot longer than thirty years.

However long the transicion period, it is clear that huge investments must be made both in infrastructurc and the industrial sector if the present DPRK ever is to have a per capita income equivalent to the ROK. Moreover, in the event of reunification, it is highly likely that these investments will conne from the South, meaning that savings in the South will be intermediated into invesement in the North. Exactly low much investment would be needed or likely be undertaken is not clear ro anyone. To this end, efforts have been made to estinate rulevant figurcs, including by Marcus Voland of the IIE. Noland's estimates are conclitional, but he cstimates that if technolngical convergence is at $2 \%$ per annun (chis represents the rate at which total factor productivity in the North is assumed to converge with that of the South), and if per capita income in the North is to rise to $60 \%$ of the level in the South in ten years, there will have to be transfers to the North (mostly taking the form of investment) on the order of $\$ 600$ billion (Noland 2000). 'The anouns of nceded transfer declines wher a thigher rate of convergence of total factor productivity is assurned. However, this rate of comvergence is negative at the present time, i.e., total factor productivity growth rates in the South are higher than in the Nortl, even thotigh the absolute level of total factor productivity in the South is nuch higher than in the North. In the unlikely cvent that this convergent rate was to be $12 \%$ per annum, the total transfer needed drops to L:\$\$?) billion.

Noland (2000[a4]) notes that his cstimates might suffer from a number of inadequacies, including, most importantly, that some dynamic effects that might accrue to reurification, but are impossible to quantify, are not accounted for in the underlying model used to make these estimates. Such effects would include, inter alia. changes in the scctoral composition of output, e.g., through the creation of acivities in sectors that do nor currently exist there. But as proviously implied, there is lietle idea as to what dynamic effects of these sorts mighe occur, thus making it is impossible to estimate how larese their effects mightit be (ses: Noliand 200/3). Having said this, Noland $(20)(1, a 5\}\}$ uses a computable gencral equilibrium model that can capture both static and some dynamic effects of economic integration, and is iadecel probably the best available model for this type of analysis.

Noland (200/5a6]) provides a list of other estimates that run a hige gamut, from as low as L\$\$225 billion over ton years to as high as US\$1, 00 billion. Estimates of the South Korean govermment are that costs mill be between about is\$300 billion: and L\$\$600 billion. Thus, all estimates suggest that the costs will be in hundreds of billions of clollars, but there is very wide variance in how 
many hundred of billions of dollars will be required.

\section{ECONOMIC EFFECTS ON OTHER COUNTRIES}

If estimating the effects of reunification on South Korea is difficult, estimating effects on other countrics is even more so. This is so if for no other reason than that thcse latter effects depend in some large measure on the former effects; thus, if one cannot estimate the former correctly, one stands almost no chance at the latcer.

Having said this, howcrer, it is likely that onc main effect of reunification during the inirial decade following reunification would almost surely be that Korca's currene trade and current account surplus will decline and perhaps even become negative. The effect of this from the usual morcantilist point of view (which dominates the actual conduct of relations among countries with respect to international trade, to the perpetual horror of economists), would be calming: Korea's major trading parners would either import less from Korea relative to their GDP than at present, or would export more. Both might bc possible (more exports to Korea and less imports from Korca), though the effect would more likely be morc exports to Korea rather than fewer imports from Korea.

In 2003. South Korea exported LS $\$ 201.3$ billiun and imported LS\$175.6 billion worth of goods and services, leaving the balance of trade at about US\$25.7 billion. However, South Korea runs a deficit on intangibles, such that the current account balunce was a surplus of only US $\$ 12.3$ billion. North Korea's exports in 2003 toraled about US\$1 billiou and irs imports about L5\$2 billion, suggesting a trade deficit of US\$1 billion. As intangibles are noc accounted for in available dara, it is assumed that the current account deficit of the DPRK was also about US\$1 billion. Combining the two, the overall current account surplus of the two Koreas thus was a modest US\$11 billion.

But as suggested above, the effect of reunitication would almost surely be to reduce this surplus and likely to tender it negative. In other words, Korea would likely go into a period of current account and trade account deficits. Why is this? It is simply because investment requirements in the North would boust the combined investment in both countries and, as noted ahove, the investmen would largely be financed from the South. At the same time, savings in the South would likely not rise. As is widely noted in international economics, the trade balance of a nation is governed by the overall balance of investment and savings (where a public sector deficit counts as dissaving and a public sector surplus as positive saving, and where the current account can interact with savings and investment, i.e., $S$ and $l$ should not be considered exogenous in the formula just below but, rather, either might be affected by net incernational capital inflow or outflow, which in turn are partly decernined by the current account balance) according 
to the following standatd formula (for derivation, see Krugman and (Obstfeld 2002):

$$
(\mathrm{X}-\mathrm{M})=(\mathrm{S}-\mathrm{l})
$$

where $\mathrm{X}$ is exports, $\mathrm{M}$ is imports, $\mathrm{S}$ is national savings net of public scctor surplus or deficit, and $I$ is investment. Thus, a trade account surplus is exactly the mirror image of the excess of national investment over national savings (i.e., the magnitudes are the same but the signs are reversed). If investment increases but savings stays constant, then the trade surplus will diminish - or. if there is a trade deficit, this will increase.

Given this, it would apperar that if total investment in the combined Koreas was to risc by US\$20 billion to as much as $\operatorname{CS} 170$ billion per year, and if there was no change in savings, then Korea's current account would become negative and stand at something between LS - 9 billion and L5 - 161 billion per annum, which is of course a wide range. The latter figure would likely be unsustainable if attained and external considerations almost surely put some constraint on the rate at which infrastructure and other capital could be added in the North.

the above depends upon savings in Korea remaining constant. This might be so, given 1) initial low incones in the North such that rises in income, at least in the early ycars following reunification, would be devoted to rising consumption and not rising savings. This would be consistent with Gemmany's experience following reunification. However, it should be noted that in several Asian cconomies, inclusfing in the ROK and in Taiwan (and, apparently, in present-day mainland China), household savings rates rose as per capita income rose, even when the latter was still quite low by the standards of the high income countrics. In addition, 2) savings in South Korea have on trend been falling. The net national savings as a percent of GDP in 1946 was $22.7 \%$, but this percent was only $18.7 \%$ in 2003. Given the trend, it would be difficult to predict that net national savings would rise following reunification and an assumption of no clange secms a bit conservative.

These are, howeves, very dicey estimates that have, as already admitted, large potential to be: wrong. Some things to consider in this mateer include the following:

1) Although savings in the South would not likely rise for reasons already indicated, as per capita income in the North rise, savings as a percent of GDP might increase (this was the experience in the South; though the ROK remained very poor in the 1960 s, national savings as a percent of GDP were very low but rose sharply as per capita national income rose). On this, however, it should be noted that the experience of German reunification runs somewhat councer to this proposition, i.c., the former East Germany for some time seemed to be a pit into which the former West Germany threw money.

2) It is quire possible that under reunification, investonent rates in the South would decline as savings are transferred to the North. This would be consistent 
witls the German reunification experience. Moreover, under standard cconomic: growth theory, investment rates in the South mighe be expected to decline: under any circurnstances as incomes there converge to those of the very highest income nations. Thus, even if additional investment in the Norch were to be several tens of billions of dollars over a period of ten years, the total increase in investment of the two Koreas might be well less than this increment in the North. The effect would be a reduced combined current account deficit.

3) Even if the combined Koreas were to experience current account deficits, as already suggested, Korean exports would not likely decline. 'The ROK's industrial structure is simply too export oriented for this to happen. This is in spite of the fact that, over time, consumer demand in the North would likely grow rapidly. This demand could not possibly absotb the excess of supply over demand in most of South Korca's major export-oriented sectors, such as electronics, automobiles, and shipbuilding (although internal demand for steel and perhaps even telecommunications equipment and petrochemicals, all sectors with current trade surpluses in the South, could rome to equal domestic supply and wipe out those surpluses). Morcover, one might expect the North to develop export capabiliries, perhaps even signaling Korea's return to the export of labor intensive goods such as textiles, apparel, and footwear.

1) Given the above, a trade deficit in a unified Korta would likely be greater than the current account deficit and emerge as the result of incrcased demant for imports rather than reduced exports. Both exports and imports would grow as a percent of GDP, but with the latter growing faster than the former. As indicated carlicr, this would in net likely reduce mercantilist trade tensions between Korea and its trading partners, but some sector-specific tensions might persist nonetheless.

Trade is not, of course, the only vehicle by which Korean unification can exert economic effects on other nations, although trade elfects are more likely to be politicized than others. Closely related to trade, for cxampls; is forcign dirca investment (FD), which can generate either new exports or imports for the host nation (or both) and an also exist primarily to service the local conomy using lecal inputs.

To begin on this subject, it should he noted that there are currently threc Special Economic Zones in the DPRK that are meant to draw in FDI (for a comprehensive treatment of these zones, see lee 2004), modeled loosely on similar and highly successful zones in China. These are the Rajin-Sonbong complex in the northeast corner of the country, established in 1991, the Kaesong Industrial complex, created in 2000 (South Korean group Hyundai is the major investor), and the Sinuiju Special Administrative District, created in 2002 and apparently meant to primarily serve direct investors from China. 'The first zone was untavorably located and, although it drew in as much as US\$ $\$ 88$ million in projects, this is in modest sum, 
the area seems to be in decline, and is now generally regarded as a failure. By contrast, both of the latter zones are favorably situated but have not been highly successful in attracting investment. At Sinuijiu, a Chinese-Dutch tycoon, Yang Bin, was initially appointed as CEO but later was arrested in China on corruption charges. One reason might be that Yang planned for Sinuijiu to be more of a playground, with gambling and "adult entcrtainment," than a serious industrial zone, and Chincse authorities might have taken some exception to this. In late 2004 , there was a North Korean announcement that Sinujiu would be closed, rhough this is not confirmed.

Kaesong has been a somewhat brighter experience than either Rajin-Sonhong or Sinuiju, but not exactly an overwhelming success: To date, only about 1,800 North Koreans are employed in the zone, managed by about 300 South Koreans who have at least remporarily relocated there. Reasons for Kaesong's lackluster performance include: 1) financial difficulties of the Hyundai companies that cmerged following creation of the Kaesong zone; 2) inefficiencies in the administration of the zones and, according to some reports, significant corruption; and 3) poor infrastructure linking the zones to the outside world (Ahn et al. 200-4). Presumably, ihese problems, or at least the larter two, would be corrected in the event of Korean reunification. At the present time, there are plans to enlarge Kacsong so that upwards of 300 factorics would cventually be located there. The zone has taken on some political/military significance, as it lies on the main (and narrow) route by which either North or South Korea would invade the other. If fully developed, it would posc a significant obstacle for armies advancing in either direction.

Would, then, the North become a magnet for FDI in the event of Korean Reunification? It is easy to envisage two quite different but equally plausible scenarios. The first is that in the event of economic reforms that would almost surely come with reunification, the Norch would become such a magnet by virtue of its relatively low cost but litcrate (and likely hard-working) labor force, This was the case of China, especially after then-premier Deng Xiao-ping's famous "Trip to the South" in 19\%1 and the econumic reforms that followed this trip. FDI in China thereafter burgeoned, where much of it was so-called "export platform" FDl. As a consequence, foreign-invested enterprise became the major engine of enormous growth in both China's exports and imports, as well as a major engine of overall Chinesc growth (see Graham 2004 and Lcmoine and Ünal-Kesenci 2004). Perhaps recognizing the benefics to home and host country alike as a result of their own experience, China has in fact become a direct investor in North Korea, mostly in the Sinuji zone. But at this monent, these Chinese investments are inore "roe-holds" than anything elsc.

Here, however, we seck to look beyond the present timc. In this first scenario of a future reunified Korea, the North becomes a magnet for FDI not just from China and prescnt-day South Korea, but from all over the world. Major international companies from Europe, the United States, Japan, and elsewhere would invest 
in the North, turning the former North Korca into an export platform of major proportions. This type of scenario seems to be playing out today not only in China, but also in formerly Communist "transition" "conomics such as the Czech Republic, Hungary, Poland, and Slovakia. If this scenario is realized, it is quite possible that the predictions of a reunified Korea having a persistent balance of payments deficit on current account for some number of years could be proven wrong.

But the second scenario suggests that although North Korea has abundant supplies of telatively low.cost but lictate labor, in the event of reunification, subtle barriers woule! exist that would retard much FDI from reaching the North. As happened in the South, investment opporcunitics would bx: scized by the established chatebols (conglomerates) of South Korea. In time-tested fashion, these groups woukd cnlarge their debt (and perhaps even their forcign ownership to raise additional equity) to finance large undertakings in the North. Thus, while there would be massive investment in what is now lorth Korea from outside the area, it would be by enterprises based in the South and would not qualify as FDI. In fact, for the moment, at the Kaesong Industrial Park in the . Vorch, foreign investment is linvited to South Korcan firms (and, for all practical purposes, to investment from companies formerly in the Hyundai group).

Which of these scconarios mighte prove more correct is difficult to predict. $\Lambda$ bove all clse, it must be kept in mind that both these scenarios, and indece all of the points made in this section, are speculative. These guresses are simply guesses. Moreover, there are issues that have nor been addressed but arc of importance economically, such migration between North and South in the event of reunification. As such, this author concludes in the same fashion as TV political satirist Jennis Miller: "This is just my opinion, I could be wrong."

\section{REFERENCES}

Ahn, Choong-Yong, ed. 2004. Nimth Korea Develigment Reprirt 2003/2004. Seoul: Korea Institute for International Fconomic Policy (KIEP).

Babson, Bradley and Yoon Deok-Ryong. 2004. How to Finance North Korea's Capital Requirements for Economic Recovery. East Asion Retieu 16(2): 65-96. Eberstadt, Nicholas. 2004. North Korca's Survival Game: Understanding the Past, Thinking about the Future. In A New International Engazement Framework for North Kores: Contending Perspectives, eds. Choong-Yong Ahn, Nicholas Lberstadt, and Young-Sun I.ce. Washington, D.C.: Korea Economic Institute.

Graham, Edward M. 2004. Do Export Proccssing \%ones Attract liDI and its Bencfits: the Fxperience from Chinis. Intemational ficonomics and Policy 1(1): 87-103.

Krugman, Paul R. and Maurice Olstfeld. 2002. International Eionomis: Theory and Policy. Sth ed. Reading, Massachuscets: Addison Wesley.

Lec, Jong-Woon. 2004. Current Status and Future Tasks of the NCw SE7.s in 
North Korea. Jotmal of International Fionomic Stzidies 8(2): 121-44.

Lemoine, Françoise and Deniz ünal-Kesenci. 2004. Assembly 'l'rade and Technology

Transfer: The Case of China. W'orld Development 32(5): 829-50.

Noland, Marcus. 2000. Amiding the Apocalopse: The Future of the Two Koreas. Washington, D.C.: Institute for Intermational Economics. 2004. Korea alter Kint Jong-il. Washington. D.C.: Institute for

International Liconomics.

Von Hippel. David, Timothy Savage, and Pecer Haycs. 2005. North Korean Energy Sector: Current Sratus and Scenarios for 2000 and 2005. Available: hetp:it wiww ndutilus org.

\section{ENDNOTES}

Note: HFCC is not wo be contused with the forner liguadai filectricil company (IJEC), row the troubled firm Iynix.

Note: Facts and figures in the tolowing are trom L.S Central fotelligence Agency. The Wirld lacthw, 2005 o: anc author calculations hased on fates and figures from this source.

Nise: Power parity figdres are used because nominal comparisons between the per capicia GDP it the two Koreas is difficult as scane data exists tio: the North.

With resuest to these and iul orter data pereainirg to Vorch Kotca presented in this puper, it must be remembered that theee is no rejiable data sousce for North Korea and. hence, all comparisiras

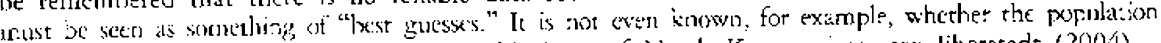
figute cited above is really accurate: On this issue of Nirth Korean cata. sce libestadt (2004)

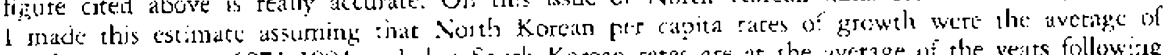

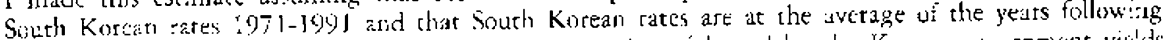

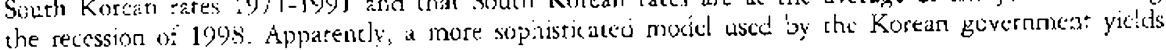
alroust exactly :he souric result.

Note: Mos: cconor.ic ileory would predict that total factor oroductivity is likely to grcew :aster in

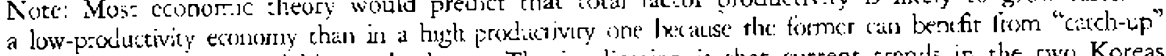
ctícets that are not avalahle to the lates. The implication is chat cutrent irends in the rwo Koreas aze comrary to what reory might predici. 